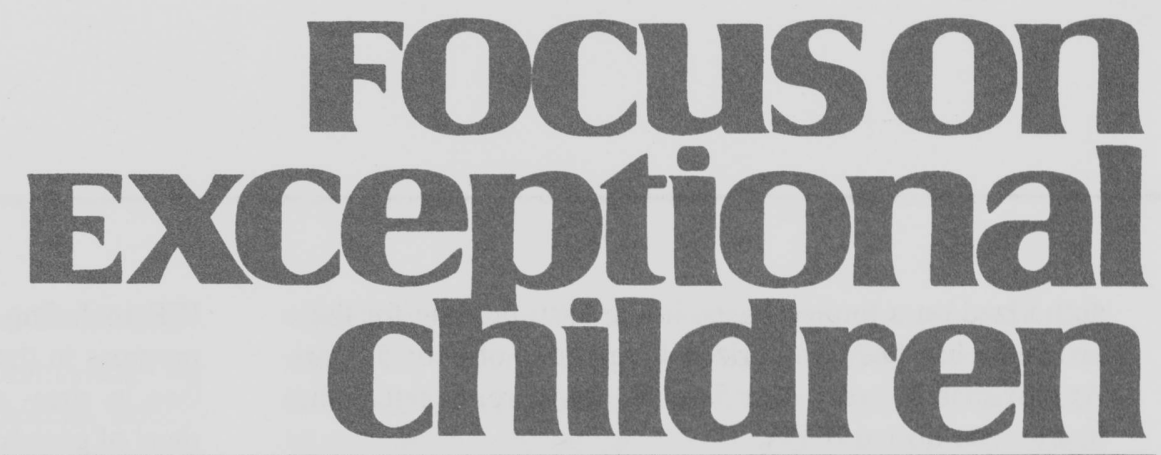

\title{
Individuals with Disabilities Education Improvement Act of 2004 and IDEA Regulations of 2006: Implications for Educators, Administrators, and Teacher Trainers
}

\author{
Mitchell L. Yell, James G. Shriner, and Antonis Katsiyannis
}

The Individuals with Disabilities Education Improvement Act of 2004 (hereafter IDEIA) was signed into law by President George W. Bush on December 3, 2004. The law reauthorized and made important changes to the Individuals with Disabilities Education Act (IDEA). On August 3, 2006, the U.S. Department of Education released the Regulations implementing IDEIA. Because of the crucial importance of the IDEIA to students with disabilities, school personnel have to be aware of the changes and challenges that these amendments pose to educators. In this article we will summarize these changes and challenges.

First we briefly review the reauthorization process. Next we consider the influential effect that No Child Left Behind and two major reports had on Congress when it reauthorized the Individuals with Disabilities Education Act. Third, we discuss major changes to the law. We conclude with an examination of how the law will directly affect special educators, administrators, and teacher trainers.

As we address these topics, we caution the reader that (a) courts will clarify many of the provisions, and (b) states will have to change their special education regulations to align with IDEIA. To understand and implement IDEIA appropriately, teachers and administrators will have to monitor these due process hearings, court cases, and state law, regulations, and guidelines.

\section{THE REAUTHORIZATION PROCESS}

When Congress passes a statute that appropriates money, it may fund the statute on either a permanent or a limited basis. If a law is funded on a permanent basis, the funding will continue as long as the law remains unchanged unless Congress amends the law or repeals it. Congress also may appropriate funds for a statute on a limited basis; in this case, the funding period will be designated in the statute. When this period of time expires, Congress has to either reauthorize funding or let funding expire. Part $\mathrm{B}$, the section of the IDEIA that creates the entitlement to FAPE and provides federal funding to the states, is permanently authorized. Part C and the discretionary or support programs in Part D are

Mitchell Yell is affiliated with the University of South Carolina, James Shriner with the University of Illinois, and Antonis Katsiyannis with Clemson University. 
authorized on a limited basis. In the past, funding for these programs has been authorized for periods of 4 or 5 years. Approximately every 4 or 5 years, therefore, Congress has had to reauthorize IDEA.

IDEA has been amended numerous times since its initial passage in 1975. In some years the changes have been relatively minor; and in others the changes have been substantive. For example, substantial changes were made to the law in 1986, when Congress granted authority to courts to award legal fees if parents prevailed under this statute, and it provided additional funding for children ages birth to 2 and required services for children ages 3 to 5 . In the 1990 reauthorization, Congress changed the name of the law, added autism and traumatic brain injury as distinct disability categories, and specified that a student's individualized education program (IEP) must include transition services when he or she turns 16 years of age.

In 1997, Congress strengthened the role of parents, emphasized student progress, encouraged nonadversarial resolution of disputes by adding mediation procedures, added disciplinary procedures, and made extensive changes to the

\section{FOCuSOn Exceptional children}

ISSN 0015-511X FOCUS ON EXCEPTIONAL CHILDREN (USPS 203-360) is published monthly except June, July, and August as a service to teachers, special educators, curriculum specialists, administrators, and those concerned with the special education of exceptional children. This publication is annotated and indexed by the ERIC Clearinghouse on Handicapped and Gifted Children for publication in the monthly Current Index to Journals in Education (CIJE) and the quarterly index, Exceptional Children Education Resources (ECER). The full text of Focus on Exceptional Children is also available in the electronic versions of the Education Index. It is also available in microfilm from Serials Acquisitions, National Archive Publishing Company, P.O. Box 998, Ann Arbor, MI 48106-0998. Subscription rates: individual, $\$ 42$ per year; institutions, \$56 per year. Copyright (C) 2006, Love Publishing Company. All rights reserved. Reproduction in whole or part without written permission is prohibited. Printed in the United States of America. Periodical postage is paid at Denver, Colorado. POSTMASTER: Send address changes to:

$$
\begin{gathered}
\text { Love Publishing Company } \\
\text { Executive and Editorial Office } \\
\text { P.O. Box } 22353 \\
\text { Denver, Colorado } 80222 \\
\text { Telephone (303) } 221-7333
\end{gathered}
$$

\section{EDITORIAL BOARD}

Lisa Dieker

University of Central Florida
Paula Maccini University of Maryland

Marleen Pugach

University of Wisconsin-Milwaukee

Susan T. Warhover Editor
Stanley F. Love Publisher
IEP, including requirements regarding (a) participation and progress in the general education curriculum, (b) participation in state- or districtwide assessments, and (c) involvement of general education teachers. The 2004 reauthorization and the 2006 regulations also made important changes to the IDEA. Before we discuss the changes in the law, we discuss two important influences on the 2004 reauthorization.

\section{INFLUENCES ON REAUTHORIZATION}

When Congress reauthorized IDEA, three key factors were heavily influential. The first was enactment of the No Child Left Behind Act of 2001 (NCLB), arguably the most significant piece of federal legislation since the Elementary and Secondary Education Act was originally passed in 1965. The second and third factors were the findings and recommendations of two influential reports: Rethinking Special Education for a New Century (Finn, Rotherham, \& Hokanson, 2001) and A New Era: Revitalizing Special Education for Children and Their Families, by the President's Commission on Excellence in Special Education (U.S. Department of Education, 2002). We discuss these two influences next.

\section{No Child Left Behind}

No Child Left Behind was intended to improve the academic achievement of students across the United States. The law has focused national attention on improving the academic achievement of the nation's 48 million students by establishing the 2013-14 school year as the deadline for public schools to ensure that all students will be proficient in reading and math. The law also established a rigorous accountability system for states and public schools that involves rewards and sanctions based on students' performance.

In addition, NCLB required that by the 2005-06 school year, all students have to be taught by highly qualified teachers in environments that are safe, drug-free, and conducive to learning, and all students will graduate from high school. ${ }^{1}$ Finally, NCLB required that schools must implement evidence-based practices. No Child Left Behind has resulted in more pervasive involvement of the federal government in educational matters and will have a profound effect on the education of students with disabilities (e.g., AYP requirements, graduation and drop-out requirements).

\footnotetext{
1 The core academic subjects are English, reading/language arts, mathematics, science, foreign languages, civics, government, economics, art, history, and geography. If a teacher instructs in one of these core subjects, he or she must be highly qualified in that area. If a teacher instructs in more than two of these core subjects, he or she must be qualified in all the subject areas taught.
} 


\section{Reports of the Status and Future of Special Education}

In 2001, President Bush appointed a commission, the President's Commission on Excellence in Special Education, to study the current condition of special education practice in the United States and to issue a report prior to the reauthorization of the IDEA. The commission, chaired by Terry Branstad, held 13 public hearings in cities throughout the nation and heard testimony from hundreds of individuals, including noted experts in special education, educational finance, administrators, teachers, educational researchers, parents, and students with disabilities who either testified before the commission or submitted written comments. On July 1, 2002, the President's Commission issued its final report entitled, A New Era: Revitalizing Special Education for Children and Their Families (U.S. Department of Education, 2002). Figure 1 contains information for viewing, downloading, and ordering the print copy of this report.

In 2001 the Thomas B. Fordham Institute issued a series of 14 reports entitled Rethinking Special Education for a New Century (Finn et al., 2001). The purpose of these reports was to examine special education services and make recommendations to improve the delivery of educational services to students with disabilities. Figure 2 contains information for viewing, downloading, and ordering the print copy of the report.

These two reports identified limitations of the present special education system, particularly with respect to program eligibility, service delivery, and student outcomes. Specifically, the reports delineated how special education has become too compliance-based. A compliance-based model of education is based on following certain specific, legally required procedures and defines success of education in terms of effectively documenting routine compliance or conformity in education (Hassel \& Wolf, 2001; U.S. Department of Education, 2002).

The problem with overreliance on the compliance model is that schools emphasize the process rather than results. The special education system, according to the President's Commission Report, has become so driven by complex regulations, excessive paperwork, and ever-increasing administrative demands that complying with these demands, rather than concentrating on early and strong intervention using research-based procedures, too often has become the focus of special education. These reports concluded that a compliance-based approach to special education must be transformed into a more results-oriented approach that will place student achievement, excellence, and outcomes above process.

Additional limitations of the compliance-based approach are its inflexibility and the complexity of regulations. Inflexibility means that educators and local districts are unable to adjust instruction or policy to benefit the individual needs of each student because the regulations require them to follow a distinct set of rules that apply to special education across the board. Moreover, the complexity of requirements often

PDF version: http://www.ed.gov/inits/commissionsboards/whspecialeducation/index.htm Order copy: http://www.ed.gov/inits/commissionsboards/whspecialeducation/reports.images/Pres_Rep.pdf

Source: A New Era: Revitalizing Special Education for Children and Their Families, President's Commission on Excellence in Special Education (Washington, DC: U.S. Department of Education, 2002). Retrieved on July 11, 2002, from the websites listed.

FIGURE 1

Website for President's Commission on Special Education

PDF version: http://www.edexcellence.net/Doc/Special_ed_Final.pdf

Order copy: http://www.edexcellence.net/institute/topic/topic.cfm?topic_id=15

Source: Rethinking Special Education for a New Century (335-347), by C. E. Finn, A. J. Rotherham, \& C. R. Hokanson (Eds.) (Washington, DC: Thomas B. Fordham Institute, 2001). 
becomes so demanding that educational personnel are unable to comply with the requirements successfully (Hassel \& Wolf, 2001).

Although educators must comply with the requirements of the law and the process of special education has to be reviewed and monitored, both reports clearly assert that the actual result of special education programs in increasing student achievement is the only valid way to determine effectiveness of education. The authors of both reports suggested developing a special education model based on compliance but placing the most importance on student results.

To move away from the compliance-based model of education, Hassel and Wolf (2001) suggested in no uncertain terms that educators and administrators become "obsessed with results" (p. 322). Educators and administrators must have access to a wide range of research-based educational procedures so they can tailor students' educational programs to meet their unique individual needs. Emphasis on individual needs rather than on a compliance-based model will produce far greater achievement results than the one-sizefits-all approach currently in practice.

Both reports also noted that the special education system relied on an intervention model in which students have to fail before they are targeted for possible special education intervention. By using the "wait to fail" model instead of stressing prevention and early intervention, students with disabilities often do not get the help they need early enough to benefit from special education. Both reports, therefore, emphasize the importance of adopting a special education model based on prevention, early and accurate identification, and aggressive intervention using research-based strategies and procedures.

Other benefits of a prevention and intervention model include

- decreasing the number of students labeled as having a disability because of poor instruction;

- merging special and general education into one united system that seeks to provide quality, effective education to all students (U.S. Department of Education, 2002); and

- making funding contingent on improved educational outcomes of special education, not merely the identification of students (Finn et al., 2001).

In addition, the reports recommended establishing high goals for students in special education. For example, Hassel and Wolf (2001) asserted that a goal-setting system must make attainment of individual goals the central aim, which in turn will guarantee achievement of school-wide goals, school district goals, and so on up the ladder to achievement of national goals. The report by Finn et al. (2001) also recommended that instead of providing funding to schools based solely on identifying students with special needs, funding should be provided based on proof of the use of successful, results-based, special education programs. Moreover, rewards should be provided based on a school's exemplary performance. In summary, the reports recommended that when reauthorizing the IDEA, Congress should stress the importance of looking at real results instead of compliance and process. Clearly, the authors of these reports believed that this could be accomplished by retaining the legal and procedural safeguards necessary to guarantee FAPE while ensuring that studențs with disabilities are identified early in the educational process and then intervening with research-based practices to improve student outcomes. We next examine some of the major changes in IDEIA.

\section{MAJOR CHANGES IN IDEIA}

The primary goal of IDEIA is to improve outcomes for students with disabilities. The law accomplishes this in a number of ways, including

- emphasizing the substantive requirements of the special education process;

- aligning IDEA with NCLB's provisions such as adequate yearly progress (AYP), highly qualified personnel, and evidence-based practices; and

- altering eligibility requirements.

Finally, in IDEIA, Congress made important changes to the IEP, the disciplinary process, and the dispute-resolution system. In the following discussion, we summarize major changes in IDEA.

\section{Emphasizing the Substantive Requirements of IDEA}

An important provision of IDEA requires that "a decision by a hearing officer shall be made on substantive grounds based on a determination of whether a child received a free appropriate public education" (IDEA, 20 U.S.C. $§ 1415$ (f) (3)(E)(I); IDEA Regulations, 34 C.F.R. $§ 300.315$ et seq.). The emphasis on substantive grounds means that when making rulings in due process hearings, hearing officers will examine the results of a student's special education program; for example:

Was a student's special education programming based on his or her unique educational needs as determined in the assessment?

Were a student's measurable annual goals calculated to provide meaningful educational benefit?

Were a student's special education services based on peer-reviewed literature? 
Was a student's progress measured?

Were changes made to a student's program if he or she did not progress satisfactorily?

In IDEIA, Congress clearly emphasized that students should receive meaningful educational benefit from their special education programs.

Educators can ensure that their individualized education program (IEP) planning teams develop and implement a free appropriate public education, an education that confers meaningful educational benefits to students, by attending to the following requirements (Yell, Drasgow, \& Lowrey, 2005):

1. Teams must conduct relevant assessments.

2. Based on these assessments, IEP teams must develop meaningful programs that include measurable annual goals and appropriate special education and related services; moreover, these services must be based on peer-reviewed literature.

3. IEP teams and special education teachers must monitor and report regularly on the educational progress of students in their programs.

4. IEP teams and special education teachers must adjust instruction when a student's progress is not sufficient to meet his or her goals.

An example of how Congress emphasized the importance of meaningful programming in IDEIA can be seen in the importance placed on writing measurable goals and monitoring progress. The IEP must include a statement of how the child's progress toward the annual goals will be measured, including quarterly or other periodic reports, concurrent with the issuance of report cards, that delineate the child's progress toward meeting the annual goals.

\section{Aligning IDEA With NCLB}

A major goal of Congress in the reauthorization was to align IDEA with NCLB. The primary ways in which this was to be accomplished were in IDEA's requirements that (a) special education teachers be highly qualified, (b) students with disabilities be included in statewide assessments, and (c) special education services be based on peerreviewed research.

\section{Highly Qualified Personnel}

The influence of NCLB on the reauthorization of IDEA is apparent in the "highly qualified" teacher requirements. According to Whitehurst (2002), the quality and skill of a student's teacher is an extremely important factor in student achievement. Congress recognized the importance of having well-prepared teachers in special education classrooms when it included the "highly qualified" provisions from the NCLB in IDEIA.

IDEIA requires that teachers who (a) were hired by a school district after the start of the 2002-03 school year, (b) are teaching a core academic subject, and (c) are teaching in a program supported with Title I funds be highly qualified when they are hired. Teachers who (a) were hired prior to the 2002-03 school year, (b) are not teaching a core academic subject, or (c) are not teaching in a Title I program have until the end of the 2005-06 school year to become highly qualified.

To become highly qualified, teachers must meet the following three requirements in education, certification, and competence:

1. Special education teachers must hold a minimum of a bachelor's degree from a college or university.

2. Special education teachers must have full state teacher certification or licensure to teach special education, which includes certification met through a state-approved alternative route. Provisional licenses, emergency waivers, or temporary permits are not permitted. Usually this means that a teacher has passed a state's special education licensing requirement to be a special education teacher. If a state licenses special education teachers through an alternative route, the program must

a. be a high-quality professional development program that is sustained, intensive, and classroomfocused; and

b. involve intensive supervisions that consist of structured guidance and ongoing support (IDEA Regulations, 34 C.F.R. $\S 300.318(2)$ ).

3. Special education teachers must be able to demonstrate subject-matter competency in the core academic subjects in which they teach. Special education teachers can demonstrate subject-matter competence by passing a state-approved test. The individual states determine the structure and content of these tests.

The subject-matter competency requirements are different for teachers at the elementary level and the middle and secondary levels. Elementary special education teachers must demonstrate subject-matter competency by passing a rigorous state test of knowledge and teaching skills in reading, writing, math, and other areas of basic elementary curriculum (this requirement can be met by passing a rigorous state teaching examination). Middle or high school special education teachers who teach multiple subjects must demonstrate competence in all the core academic subjects in 
which they teach in the same manner as is required for an elementary, middle, or secondary school teacher.

Special educators, administrators, and teacher trainers will have to pay attention to how their respective states will respond to these requirements. For example, NCLB, and therefore IDEIA, allows states to design a standard for determining if certain teachers demonstrate subject matter competency by developing high objective uniform state standards of evaluation (HOUSSE). The HOUSSE standards differ from state to state.

When a special education teacher teaches core academic subjects to students who are assessed against alternate achievement standards (i.e., below grade-level standards), the teacher can demonstrate competence in the same manner as an elementary teacher would. This is true even if the special education teacher teaches at the secondary level. If the special education teacher teaches multiple core subjects at the secondary level, and the level of instruction is at that level, the state education agency will have to provide guidance regarding highly qualified status.

Moreover, if the special education teacher is qualified in math, language, or science when he or she is hired by a school district, the teacher will have an additional 2 years to demonstrate competency in the other areas. Special education teachers who teach multiple core academic subjects may also demonstrate competence through their state's HOUSSE process.

Teachers and administrators need to be aware of the "highly qualified" paraprofessional requirements of NCLB because these standards also apply to paraprofessionals who work in special education programs. NCLB allows paraprofessionals to provide instructional support services only when they are directly supervised by a teacher (Yell, Drasgow, \& Lowrey, 2005). The teacher must plan all instructional activities in the classroom, and he or she must evaluate the achievement of the students who work with the paraprofessional. The law also clearly specifies what duties paraprofessionals may perform. Paraprofessionals may assist a teacher with

- one-to-one tutoring,

- classroom management,

- computer instruction,

- parent involvement activities,

- educational support in a library or media center,

- translator services, and

- instructional support activities under the direct supervision of a qualified teacher.

If a student in special education is taught for 4 or more consecutive weeks by a special education teacher who is not highly qualified, the school district must notify the parent.
But there is no right of action (i.e., a parent cannot sue a school district) because of the school's failure to provide a highly qualified teacher.

\section{Accountability and Adequate Yearly Progress}

No Child Left Behind aims to (a) increase the academic performance of all public school students, and (b) improve the performance of low-performing schools. The law accomplishes this by requiring states to identify the most important academic content for students to learn, and then by assessing students to determine if they are learning this content. The purpose of the state-defined standards is to provide guidelines to schools, parents, and teachers that tell them what achievement will be expected of all students (Yell, Drasgow, \& Lowrey, 2005).

The NCLB also requires that states implement a statewide assessment system that is aligned to the state standards in reading/language arts, math, and eventually science. The purpose of the statewide testing is to measure how successfully students are learning what is expected of them and how they are progressing toward meeting these important academic standards. To reach the goal of having every child proficient on state-defined standards by the target date, the NCLB requires every state to develop achievement standards for all public schools.

States must set state proficiency standards or goals that determine if schools and school districts are meeting the state standards. These performance standards are the criteria for increasing student achievement to meet NCLB's goal of having $100 \%$ proficiency of a state's goals in reading/language arts and math for public school students in grades three through eight by the 2013-14 school year. In addition to all students in a school, schools are required to report AYP data for the following subgroups:

- Students who are economically disadvantaged

- Students from racial and ethnic groups

- Students with disabilities

- Students with limited English proficiency

To ensure that all students, including students from each of the subgroups, are making progress toward the $100 \%$ proficiency goal by the target date, the state must set specific targets for all students each year in reading/language arts and math. These specific targets are the AYP criteria. We next describe how these provisions affect the education of students with disabilities.

Statewide Assessments. Under NCLB, the key component in measuring adequate yearly progress (AYP) is students' annual scores on statewide assessments. In NCLB, IDEA '97, and IDEIA, Congress required that all children with 
disabilities participate in these statewide assessments. Further, students with disabilities had to be calculated and reported separately in statewide assessments. The intent of these laws was to promote high expectations and accountability for all students, including students with disabilities.

Standards. Since the passage of IDEA '97, requirements for access to the general curriculum standards for students with disabilities have continue to evolve. The principle that all students should have opportunities for access to rigorous content, however, has remained a priority. In both the current rules and the proposed rules for NCLB regarding access to the general curriculum, states are required to have rigorous academic-content standards that specify what all students are expected to know and be able to do.

States' achievement standards, on which student performance is judged, must be aligned with the academic-content standards. Separate content standards for students with disabilities are permitted. States, however, are allowed to develop both alternate achievement standards and modified achievement standards for some portion of students with disabilities for whom the grade-level achievement standards are not useful in assessing their performance on state assessments.

An alternate achievement standard is "an expectation of performance that differs in complexity from a grade-level achievement standard" (Title I-Improving the Academic Achievement of the Disadvantaged, 2005, p. 74625). In general, alternate achievement standards must (a) be aligned with a state's academic content standards, (b) promote access to the general curriculum, and (c) reflect professional judgment of the highest achievement standards possible. (See 34 C.F.R. $\$ 200.1(d)$.) States may use alternate achievement standards to assess the achievement of students who have the most significant cognitive disabilities, but there should not be a significant overlap between alternate achievement standards and grade-level achievement standards.

A modified achievement standard is one that (a) provides access to grade-level curriculum; (b) is aligned with the state's academic content standards for the grade in which the student is enrolled, although the modified achievement standards may reflect reduced breadth and depth of the gradelevel content; and (c) does not preclude a student from earning a regular high school diploma (Title I-Improving the Academic Achievement of the Disadvantaged, 2005, p. 74625). As such, modified achievement standards and gradelevel achievement standards may have significant overlap. Neither alternate achievement standards nor modified achievement standards ignore the need for student-specific instruction that is not directly related to the academic content standards for general education if such instruction is necessary; however, the instruction should be a supplement to, not a replacement for, access to general curricular opportunities (Browder, Karvonen, Davis, \& Fallin, 2005; Kleinert \& Kearns, 2004).

Participation in Statewide Assessments. After NCLB required that students with disabilities be part of the accountability measures (i.e., AYP), more students with disabilities were included in state assessments. When IDEA ' 97 was passed, the primary goal of the assessment provisions of the law was to increase overall participation of students with disabilities in the statewide assessments. The law's requirements directed educators' attention to the ways by which students with disabilities could participate successfully in these assessments.

After the law was passed, Rouse, Shriner, and Danielson (2000) proposed alternative ways by which students with disabilities could participate in statewide assessment systems. The options for student participation ranged from full participation in the general assessment without accommodations to participation via an alternate assessment. Alternate assessments were a relatively new endeavor at the time and were intended generally for students for whom the general education curriculum was thought to be inadequate in addressing their specific needs.

Although accommodations and alternate assessments were allowed when testing students with disabilities, the law still required that the learning experiences of all students had to be based on the states' defined academic-content standards because no separate content standards were in place. Table 1 depicts the five possible assessment options under NCLB and, subsequently, IDEIA.

As students with disabilities participated in state assessments, however, it became apparent that some students clearly would not be able to meet the same grade standards within the same timeframe as their nondisabled peers. This led to the development of a new assessment option. Under NCLB, states are allowed to develop modified achievement standards that vary in the depth and breadth of content coverage (Title I-Improving the Academic Achievement of the Disadvantaged, 2005, Proposed § 200.1(e)) and corresponding assessments that measure achievement based on those standards.

Although more precise guidelines for participation now are in place, flexibility in determining the appropriate instructional, assessment, and performance judgment options remains (see Table 1, column 2). According to Gong and Marion (2006), states vary in the extent to which they assume that students will have been taught with a common curriculum. Nonetheless, most states recognize that for students with disabilities, learning may require "individualization of learning goals within the general frame of academic content" (p. 8). The low-to-high ratings of the flexibility 


\title{
TABLE 1
}

Options for Large-Scale Assessment by Content Area and Performance Criteria

Assessment Option

1. General assessment: No accommodations

2. General assessment: accommodations

3. Assessment: general, modified, alternate ${ }^{2}$

4. Alternate assessment

5. Alternate assessment
Flexibility of Curricular/

Instructional Focus Relative to Grade-Level Standards ${ }^{1}$

1. Low

2. Low

3. Low-Moderate

4. Low-Moderate

5. High

\section{Performance Criteria: AYP Cap}

1. Grade-level achievement standards: None

2. Grade-level achievement standards: None

3. Modified achievement standards: $2 \%$

4. Grade-level achievement standards: None

5. Alternate achievement standards: $1 \%$

\begin{abstract}
$\overline{\text { Notes: }}$
${ }^{1}$ For all students, the state's academic grade-level content standards serve as the basis of content of the assessment used and for instructional planning. Indicators in column 2 are based upon work by Gong and Marion (2006).

2 States are permitted to develop assessments for a group of students with disabilities who can make progress toward, but may not reach, grade-level achievement standards in the same timeframe as other students. No specific name has been given to these assessments. (Proposed $\S 200.1(\mathrm{e})$, Title I-Improving the Academic Achievement of the Disadvantaged, 2005.)
\end{abstract}

associated with each assessment-achievement standard combination do not mean that teachers must abandon creative and innovative classroom lessons.

Neither teaching to the test only nor relying on a single delivery method reflects effective instructional practice. When considering assessment options, the realistic view is that curricular and instructional content variances for a student whose performance is to be judged against grade-level achievement standards will be lower than those of a student whose performance is to be judged against alternate or modified achievement standards.

Accommodations in Assessment. School districts must provide access for students with disabilities to appropriate accommodations if a student needs such accommodations to participate in the statewide assessment. If the standardized statewide assessment with accommodations is not appropriate for a student, his or her progress must be measured using an alternate assessment. The student's IEP team or Section 504 decides how the student will participate in a statewide assessment. These teams may decide that a student with disabilities will take the statewide assessment without accommodations or with accommodations, or will take an alternate assessment; however, all students with disabilities must participate in the testing.

Even though IDEIA gives the IEP team the responsibility for deciding how a student participates in the statewide assessment, states may require that only "approved" accommodations be used and, therefore, not allow the use of unapproved accommodations. The House Committee Report on the reauthorization of the IDEA emphasizes the importance of ensuring that accommodation guidelines identify accommodations that do not affect test validity (H.R. 108-77, 2003). The states are responsible for determining what types of accommodations may be used, while ensuring that students with disabilities receive appropriate accommodations (70 FR 74632). Therefore, teachers and administrators must be aware of their state's policies regarding accommodations and ensure that their IEP teams and Section 504 teams understand and implement these policies.

School district IEP teams should be fully informed of the state accommodation policy and use reasoned judgment to determine use of accommodations on a case-by-case basis. They have to carefully document all accommodation decisions 
and support them with individual student data, if possible, because under NCLB and IDEIA, students who take assessments with unapproved accommodations are not to be counted as participants in statewide testing-a provision affecting AYP participation criteria (Title I-Improving the Academic Achievement of the Disadvantaged, 2005, Proposed $\S 300.160$ (e) IDEIA). An important resource for participation and accommodation decisions for all educators is the U.S. Department of Education's Toolkit on Teaching and Assessing Students with Disabilities, available at http:// www.osepideasthatwork.org/toolkit/index.asp.

Accommodations have continued to revolve around four main categories of changes to testing conditions:

1. Setting of an assessment

2. Presentation of an assessment

3. Response mode a student uses

4. Timing or scheduling for the assessment

In 2004, 46 states had written guidelines regarding the IEP team's use of accommodations (Thurlow, 2006).

Defensible decisions about the use of accommodations in assessments remain based on several key principles for consideration by the IEP team (Yell \& Shriner, 1997). First, accommodations for testing generally should reflect those that are acceptable for instruction. Experience with an accommodation for a student with disabilities during his or her instruction is one consideration that IEP teams should include when assigning assessment accommodations.

Second, accommodations that are recommended should be related to the student's specific educational need, not based on the type of disability for which he or she is receiving special education services.

Third, accommodation decisions should be made at the most precise level possible (i.e., item level, subtest level, content area level). Researchers who have examined issues regarding assessments (e.g., Sireci, Scarpati, \& Li, 2005; Tindal, 2006) have shown that the combination of student characteristics with the task demands of individual test items is the optimal level for decision making about the effect of an accommodation on student performance and the resulting inferences that can be made. Although such decisions currently are unlikely for large-scale assessment, the possibility that a student might need accommodations for some subtests of the general education assessment and not need those same accommodations or might need different accommodations for other subtests should be considered.

Finally, IEP teams must consider the possible impact of an accommodation on test reliability and validity. This requirement has grown increasingly important as states have exercised their policies on use of accommodations, sometimes without data to support a decision, and other times without due consideration to preserving the validity of assessments. Now, all states have an affirmative obligation to determine appropriate accommodations for assessments that maintain their reliability and validity and to provide guidelines to IEP teams for decision making on the use of accommodations (Pullin, 2005; Title I-Improving the Academic Achievement of the Disadvantaged, 2005, Proposed $\S$ 300.160(b)(2), IDEIA).

States must gather and make available data on the effects of the accommodation and their inferences so defensible determinations of an accommodation can be made in terms of appropriateness or inappropriateness. States should do this in accordance with professional and technical standards (Pullin, 2005), thereby giving IEP teams the best available data and guidelines for their consideration.

The above criteria, though not new, do present some interesting challenges, given the increased attention to assessment under both IDEIA and NCLB. At times, consideration of one principle (e.g., accommodations in instruction) confounds the application of another (e.g., impact on validity). The challenge will be to balance the requirements for states' delineations of valid accommodations and their appropriateness with the IEP teams' authority to determine and assign accommodations for individual students (Thurlow, 2006). Policy-level requirements for states to determine appropriate accommodation guidelines require that data on use of accommodations and their effects must be analyzed across students and tasks and over time.

Accountability, AYP, \& $1 \%$ and 2\% Rules. Although the intention of both IDEA ' 97 and IDEIA was to promote inclusion of students with disabilities in the assessment and accountability systems, neither law included guidance to assist state education agencies (SEAs), local educational agencies (LEAs), or IEP teams to determine how students with disabilities should participate in statewide assessments and how their test results of students with disabilities were treated. As mentioned previously, IEP teams could allow a student with disabilities to take the statewide test as is (i.e., without accommodations), with accommodations, or via an alternate assessment. Only students with significant cognitive disabilities were to be included in alternate assessments; the vast majority of students with disabilities were to be assessed (with or without accommodations) and judged against grade-level achievement standards.

A significant issue with respect to statewide testing of students with disabilities concerned a cap that the federal government put on the percentage of students taking alternate assessments who can be counted as proficient for purposes of calculating AYP. According to federal guidelines, for calculating adequate yearly progress, states and school districts cannot count as proficient more than $1 \%$ of the 
students with serious cognitive disabilities who take alternate assessments. Thus, if greater than $1 \%$ of a district's students take alternate assessments, all students above the $1 \%$ cap must be counted as nonproficient.

State education agencies (SEAs), however, could request a waiver from this $1 \%$ cap from the U.S. Department of Education. Furthermore, school districts may also request an increase in the cap from the SEA. When such a request is made it must include the following information: (a) an explanation of circumstances that result in more than $1 \%$ of all students statewide who are having the most significant cognitive disabilities and who are achieving a proficient score on alternate assessments based on alternate achievement standards; (b) the data showing the incidence rate of students with the most significant cognitive disabilities; and (c) the information showing how the state has implemented alternate achievement standards.

In December 2005, the U.S. Department of Education proposed rules to modify the $1 \%$ cap in response to data and research that indicated that another option, and therefore greater flexibility, was needed for those "students with disabilities whose progress in response to high-quality instruction, including special education and related services designed to address the student's individual needs, is such that the student is not likely to achieve grade-level proficiency within the school year covered by the student's individualized education program (IEP)" (2005b, 70 FR 74624-74625). Under this rule states will be allowed to develop modified achievement standards and assessments to measure students' achievement of these modified standards. States and districts will be allowed to include proficient and advanced scores of students with disabilities on assessments based on modified achievement standards in their AYP calculations subject to a $2.0 \%$ cap of all students in the applicable grades. Students eligible for assessment based on modified achievement standards may be from any disability category under IDEIA; the restriction placed on alternate assessment based on alternate achievement standards for only students with significant cognitive disabilities does not apply. The expectation is that all assessments based on either alternate or modified achievement standards will be of high technical quality and be linked to academic content standards for the grade in which the student is enrolled. These students comprise a group in which membership is likely to be highly variable and the IEP team under new guidance must determine if this option for assessment is appropriate on a yearly basis (Title IImproving the Academic Achievement of the Disadvantaged, 2005).

What specific student characteristics will justify the use of assessment based on modified achievement standards, as well as what data will be needed to support decisions, are not certain, but are likely to be a clarified and refined in the near future. What is clear is that these students are expected to meet grade-level standards at some point in time and schools should keep complete records of their actions.

At this time, it is not clear how states and districts will respond to the $1 \%$ and $2 \%$ options. States must develop guidelines to help IEP teams determine which students are best assessed via this newest option. Without these guidelines (and appropriate guidelines for alternate assessment based on alternate achievement standards) students may be inappropriately assessed, and thus be counted as nonparticipants for AYP purposes.

Nonparticipation Under NCLB and IDEIA. As stated earlier, one on the primary purposes of IDEA's assessment provisions was to promote more participation of students with disabilities in state assessments. That emphasis did meet its intended goal of overall higher participation rates for students with disabilities. As participation increased, research on use of accommodations and the effect on scores accumulated, and more precise articulations of possible assessment options emerged, professionals' application of participation decisions also have been defined further. Currently, proposed Section 300.160 of IDEIA is crafted to match NCLB for high (95\% minimum) participation rates based upon appropriate guidelines and technical soundness. Neither law as amended allows for participation of students with disabilities that does not follow state-provided guidelines for the five assessment-performance criteria options and/or yield an invalid score based upon improper the provision of accommodation(s).

NCLB has included the accommodation-use requirement in determining AYP participation rates. Proposed Section $300.160(e)(1)$ of IDEIA requires states to report on the number of children who were provided accommodations that did not result in an invalid score. Therefore, if a student uses an accommodation that results in an invalid score, the student is considered to be a nonparticipant when calculating the participation rate for AYP purposes and for state performance reporting purposes under IDEIA.

Another clarification found in Proposed Section 200.1 gives guidance to states on the use of out-of-level testing as an option for assessment. Previously, out-of-level testing was not allowed for students with severe cognitive disabilities who participated in alternate assessment based on alternate achievement standards (OSEP Memo 00-24, August 24, 2000; U.S. Department of Education, 2005a). Nonregulatory guidance issued in 2005 clarified that out-of-level testing may be used to assess students with the most significant cognitive disabilities if those tests are aligned with a state's alternate achievement standards that meet the requirements of $\S 200.1$ (d) of NCLB (U.S. Department of Education, 2005a). 
Further, proficient scores on these assessments may be used for AYP purposes, under the 1.0\% cap. Proposed Sections 200.1(e) and 200.6 for NCLB would not allow the use of out-of-level assessment as an assessment based on modified achievement standards. Students assessed in this way will be counted as nonparticipants for purposes of AYP participation rate calculations.

Of critical importance is the notion that the IEP team remains the decision-making body for all students with disabilities in an inclusive accountability and assessment system. The IEP team has the responsibility to make decisions about appropriate student participation and accommodation options for all students with disabilities. Although at times these decisions seem to be moving targets, educators have done a remarkable job of balancing students' needs with whom they work daily with the external requirements for school and system accountability. Using the tools that are available and continued sound professional judgment will continue to be the best course of action.

\section{Peer-Reviewed Research}

According to Congress and the Department of Education, schools too often rely on programs and practices that have not been proven to work, often at the expense of students (Yell \& Drasgow, 2005). As mentioned, the President's Commission on Excellence in Special Education also concluded that special education teachers often fail to adopt or implement evidence-based practices (U.S. Department of Education, 2002). Under IDEIA, students' IEPs must include a statement of the special education and related services and supplementary aids and services. Furthermore, these services must be based on peer-reviewed research to the extent practicable. If a student requires program modifications or if school personnel need supports to allow the student to receive FAPE in the least restrictive environment, a statement of these modifications or supports must also be included in the IEP.

Congress's inclusion of the terminology peer-reviewed research is significant. When an IEP team develops a student's special education program, the services that are provided must be based on reliable evidence that the program or service works. Although Congress did not define peerreviewed research, the 2006 Regulations clearly defined this term in accordance with NCLB's requirement regarding scientifically based research (IDEA Regulations, 34 C.F.R. § 300.315 et seq.). According to the language in NCLB (No Child Left Behind, 20 U.S.C. $§ 1411(\mathrm{e})(2)(\mathrm{C})(\mathrm{xi})$ ), scientifically based research applies the rigorous, systematic, and objective methods of science to examine and validate instructional procedures. This research (a) relies on direct observation and objective measurement (not speculation) to provide valid data; (b) controls, examines, or assesses factors to eliminate alternative explanations; (c) uses rigorous data analysis; and (d) is published in peer-reviewed journals. Further, all professional development activities and use of funds must be grounded in scientifically based research and must focus on improving student academic achievement. Certainly these provisions have a direct impact on school administrators serving as instructional leaders, particularly in choosing professionals to conduct inservice training activities, approving staff development activities, and evaluating teacher performance (see also Yell \& Drasgow, 2005).

What does this new requirement mean for teachers of students with disabilities? To be in compliance with this new requirement, teachers should take the following actions:

1. First and foremost, teachers must use academic and behavioral interventions that have support in the research literature. This means that teachers shouldn't use an intervention because

a. they have always used it,

b. it sounds good or feels right, or

c. a colleague told them about it.

Rather, teachers should use interventions that empirical research has proven to be successful in teaching behavioral and academic skills to students with disabilities.

2. Teachers should understand and be able to describe the research behind the interventions they use in their programs. Because this now is a legal requirement, a parent in an IEP meeting may legitimately inquire about the research base for an intervention that is being used, and it is up to the teacher to be able to respond to these inquiries. In addition, the peerreviewed research requirement certainly will result in due process hearings and litigations (e.g., a parent contends that the school is not using research-based strategies while the school contends that the procedure a parent is insisting on is not based on research). Clearly, in hearings of this nature, if a teacher is called to testify, an attorney likely will ask him or her, "What peer-reviewed research literature supports your programming?" And, of course, the attorney will already know the research base and will certainly challenge teachers on their knowledge (and adequacy of the IEP) if they cannot answer the question.

3. Teachers must keep abreast of the research base in academic and behavioral interventions for students with disabilities. This is where professional organizations (e.g., Council for Children with Behavioral Disorders, Council for Exceptional Children, and Council for Learning Disabilities) and peer-reviewed journals (e.g., Focus on Exceptional Children, Journal of Special Education, and Behavioral Disorders) 
can provide teachers and administrators with useful, up-to-date information. These organizations' state and national conferences, too, are useful sources of information on research. Local university programs in special education can be good sources of information as well. School districts will have to develop mechanisms to ensure that their teachers are fluent and current in research-based practices.

4. Teachers should keep records of the research base behind the interventions and procedures that are in a student's IEP. For example, if a teacher uses a token economy, the research that supports this procedure should be noted in the records. Records will help teachers be prepared for questions and challenges on their use of evidence-supported education practices. These records also could assist teachers in defending their IEPs and help to dissuade parents from insisting on the use of unproven practices.

This new requirement will result in stronger and more effective programs for students in special education programs.
Recent research has made great advances in the area of learning and behavior problems and effective procedures to remedy them. Knowing and implementing these researchbased procedures always has been good practice. Now it is the law.

\section{Altering Eligibility Requirements}

Another major area of change in IDEIA concerns special education eligibility decisions. Table 2 depicts changes in the eligibility and evaluation process.

School district personnel must follow four new requirements. First, a parent or SEA, other state agency, or LEA may request initial evaluation; eligibility determinations must be made within 60 days of consent for evaluation, or, if the state has a timeframe for evaluation, within that timeframe. Second, a child will not be determined to be a child with a disability if the child's fundamental problem resulted from the lack of scientifically based instruction in reading (including the essential components of reading instruction), lack of appropriate teaching in math, or limited English proficiency.

TABLE 2

IDEA 2004: Evaluations, Eligibility Determinations, Section 614

Key Points Explanation

Timelines for evaluations

Parental consent or refusal

Eligibility for
special education

Native language

Learning disabilities

Change of eligibility
Eligibility determinations are to be completed within 60 days of receiving parental consent for the evaluation or within the state-established timeframe, if applicable.

LEA cannot request dispute resolution to override a parent's refusal to consent for special education and related services. In these circumstances, the LEA is not responsible to provide FAPE, convene an IEP meeting, or develop an IEP.

A child shall not be eligible because of lack of appropriate instruction in reading, including the essential components of reading instruction (as defined in section 1208(3) of the Elementary and Secondary Education Act of 1965), lack of instruction in math, or limited English proficiency.

Evaluations are to be provided and administered in the language and form most likely to yield accurate information on what the child knows and can do academically, developmentally, and functionally, unless it is not feasible to provide or administer.

LEAs shall not be required to consider whether a child has a severe discrepancy between achievement and intellectual ability (discrepancy formula).

LEAs may use a process that determines if the child responds to scientific, research-based intervention as a part of the required evaluation procedures.

LEAs shall provide the child with a summary of the child's academic achievement and functional performance, including recommendations regarding the child's postsecondary goals (for students no longer eligible because of earning a regular high school diploma or exceeding the age of eligibility). 
Essential components of reading instruction mean explicit and systematic instruction in (a) phonemic awareness; (b) phonics; (c) vocabulary development; (d) reading fluency, including oral reading skills; and (e) reading comprehension strategies (NCLB, 20 U.S.C. §, 1208 (3)). This means that the general education classroom should be using evidence-based practices in reading instruction. If evidencebased practices are not being used, and as a result a child does not learn to read, the child cannot be considered as having a disability under the IDEA.

Third, when determining whether child has a specific learning disability, the state education agency (SEA) cannot require that school districts use a discrepancy formula for determining whether a student has a learning disability (IDEA Regulations, 34 C.F.R. § 300.307(a)(1)). Instead, SEAs must permit LEAs to use a process that determines if the child responds to scientific, research-based intervention as a part of the evaluation procedures (IDEA Regulations, 34 C.F.R. $\S 300.307$ (a)(2)). This change in the law will require school districts to determine how they will identify students with learning disabilities. Moreover, Congress strongly encouraged school districts to use a response-to-invention model for determining if a student qualifies for special education services in the category of learning disabilities.

According to the previously described report of the President's Commission on Excellence in Special Education (U.S. Department of Education, 2002), by using the traditional discrepancy model for determining eligibility for special education services in the category of learning disabilities, special education has adopted a wait-to-fail approach to meeting the needs of struggling learners. That is, students have to have failed to learn for a couple of years before they qualify under a discrepancy formula, which is a formula for determining if a student's discrepancy between intellectual ability and academic achievement is large enough to make them eligible for special education services.

The problem is that when waiting for a student to exhibit a severe enough discrepancy to qualify for services, precious time is lost, during which the student's learning problems possibly could have been remedied. A response to intervention, or RTI, model is designed to identify students who are having academic problems when these problems first become apparent, and then matching evidenced-based instruction to their educational needs. In addition, RTI models use progress-monitoring systems to track how students are responding to interventions so the interventions can be intensified when students fail to respond.

Many RTI models have three levels or tiers of response. The purpose of the first level is to provide high-quality instruction while monitoring student progress. During level two, students who are not responding to level-one instruction are provided more intensive evidence-based interventions while progress-monitoring continues. In level three, highly intense evidence-based interventions, which often include special education programming, is provided while progress monitoring continues.

The 2006 Regulations to IDEIA specify that a group of qualified professionals and a student's parents must determine the student's eligibility for special education services in the category of learning disabilities. The team may determine that a student is eligible if he or she

- does not achieve adequately or meet state-approved standards in oral expression, listening comprehension, written expression, basic reading skills, reading fluency, reading comprehension, mathematics calculations, or mathematics problem solving;

- does not make sufficient progress toward meeting state-approved grade level standards in one of the above areas using a process based on a student's response to scientific, research-based intervention; or

- exhibits a pattern of strengths and weaknesses in performance, achievement, or both, relative to state-approved grade-level standards or intellectual development.

The team also must determine that the student's achievement problems are not primarily the result of (a) visual, hearing, or motor disability; (b) mental retardation; (c) emotional disturbance; (d) cultural factors; (e) environmental or economic disadvantage; or (f) limited English proficiency. The team also must ensure that the student's achievement problems are not caused by a lack of appropriate instruction in reading or math. This should be done by (a) collecting data that show that the student was provided with appropriate instruction in general education settings by qualified personnel, (b) collecting progress-monitoring data during instruction that show a lack of academic progress, and (c) determining if the student participated in a process that assessed his or her response to scientific, research-based instruction (34 C.F.R. $\S 300.3011$ et seq.).

The IDEIA and implementing Regulations make major changes in the manner by which students are determined to be eligible for special education services in the category of learning disabilities by (a) prohibiting states from requiring that school districts use a formula that measures the discrepancy between a student's score on an IQ test and an achievement test score, commonly referred to as a discrepancy formula; and (b) requiring that states allow school districts to use a model based on how students respond to scientific, research-based interventions.

Moreover, the federal government, in both IDEIA and the implementing Regulations, clearly encourages school districts to use an RTI model. Readers should note that the federal law and Regulations prohibit states from requiring that 
school districts use discrepancy models; however, school districts may choose how they will use these to determine the presence of a learning disability as long as the identification procedures are research-based (IDEA Regulations, 34 C.F.R. $§ 300.307$ (a)(3)).

Because the federal government clearly discourages discrepancy formulas and process-based procedures to identify students with learning disabilities and strongly encourages the response to intervention, states and school districts will have to develop new identification systems. The Regulations require that the emphasis in identification be changed from a process that is concerned primarily with assessment to one that is concerned primarily with achievement and the quality of instruction and intervention. School districts' response to intervention models must include

- procedures to determine that students were provided with appropriate scientific, research-based instruction in general education (IDEA Regulations, 34 C.F.R. $\S$ 300.306 (b)(1)(i-ii) and IDEA Regulations, 34 C.F.R. $\S 300.309$ (b)(1));

- data-based progress monitoring system to continually track how students are responding to instruction (IDEA Regulations, 34 C.F.R. $§ 300.309$ (b)(2));

- scientific, research-based interventions for addressing the needs of students who do not respond to instruction and are placed in special education (IDEA Regulations, 34 C.F.R. $\S 300.320$ (a)(3)); and

- procedures for informing students' parents about the amount and nature of student performance data that is collected, information about general education services, and research-based strategies that will be used to increase a student's rate of learning (IDEA Regulations, 34 C.F.R. $\S 300.311$ (a)(7)(ii)(A \& B)).

\section{Changes to the IEP Process}

The IDEIA also made several changes to the content and development of the IEP. Content-related changes included the deletion of benchmarks or short-term objectives, the inclusion of transition services at age 16, and the need for implementing research-validated practices. Changes to the IEP development process also allowed for more flexibility regarding team-member participation and meetings. Table 3 depicts changes in the IEP process.

\section{Content of the IEP}

The following changes were made to the IEP content (changes are in italics):

1. Instead of a present levels or performance, IDEIA requires that the IEP now begin with a statement of a student's present levels of academic achievement and functional performance. Although the purpose of the statement remains unchanged (i.e., to explain the effect of a student's disability on his or her educational performance and involvement and progress in the general education curriculum), the emphasis on academic and functional performance seems indicative of Congress's emphasis on actual performance in academic and functional areas (e.g., behavioral, communication).

2. The statement of measurable annual goals must include goals in academic and functional areas, if necessary. In addition, Congress deleted the benchmarks and short-term objectives for children with disabilities, except for children who take alternate assessments. Readers should note that individual states may choose to keep the requirements regarding short-term objectives; thus, state regulations should be consulted before deciding not to include them on an IEP.

3. The IEP must include a statement of how a student's progress toward meeting his or her annual goals will be measured and when periodic reports will be provided to a student's parents. Moreover, reports must be issued as frequently as students in general education receive their report cards.

4. The IEP must include a statement of the special education and related services and supplementary aids and services ${ }^{2}$ to be provided to the student and a statement of the program modifications or supports for school personnel that will enable the student to

a. advance appropriately toward attaining his or her annual goals,

b. be involved in and make progress in the general education curriculum, and

c. be educated and participate with other students with disabilities and peers without disabilities.

5. Most important, special education programming must be based on peer-reviewed research (IDEA Regulations, 34 C.F.R. § 300.320(a)(4)).

Clearly, this language increases the importance of conducting a thorough assessment that identifies all areas of need, academic and functional, and then basing the measurable annual goals and service to be provided on those needs. Moreover, this section of the IDEIA increases the importance of writing measurable annual goals, and actually

${ }^{2}$ The 2006 Regulations define supplementary aids and services as "aids, services, and other supports that are provided in regular education classes, and other education-related settings, and in extracurricular and nonacademic settings, to enable children with disabilities to be educated with nondisabled children to the maximum extent appropriate" (IDEA Regulations 34 C.F.R. $\S 300.42$ ). 


\section{TABLE 3}

\section{IDEA 2004: Individualized Education Programs, Section 614}

\section{Key Points}

Team attendance

Alternative meeting formats

Benchmarks and short-term objectives

Peer-reviewed research

Transition

Transfer students

Multi-year IEPs

\section{Explanation}

A member of the IEP team may be excused if agreed upon by the LEA and the parent if the member's area of the curriculum or related services is not being modified or discussed in the meeting.

A member of the IEP team may be excused if agreed upon by the LEA and the parent even when the meeting involves a modification to or discussion of the member's area of the curriculum or related services. The excused member must submit his or her input to the IEP team in writing.

The LEA and the parent may agree to use alternative means of participation in meetings, such as video conferences and conference calls.

Benchmarks or short-term objectives are necessary ONLY for children with disabilities who take alternate assessments.

The IEP must include a statement of the special education and related services and supplementary aids and services, based on peer-reviewed research to the extent practicable, and a statement of the program modifications or supports for school personnel.

When a student turns 16 years of age, his or her IEP must contain measurable postsecondary goals based upon age-appropriate transition assessments related to training, education, employment, and, where appropriate, independent living skills; and the transition services (including courses of study) needed to assist the child in reaching those goals.

Within a state, the LEA is to provide the child with FAPE, including services comparable to those described in the previous IEP, in consultation with the parents, until the LEA adopts the previous IEP or develops, adopts, and implements a new IEP.

Between states, the LEA is to provide the child with FAPE, including services comparable to those described in the previous IEP, in consultation with the parents, until the LEA conducts an evaluation, if the LEA determines this to be necessary, and develops a new IEP, if appropriate.

Up to 15 states may request approval for 3-year IEPs. States are to provide assurances that the development of a multi-year IEP is optional. The parent is required to provide informed consent before a multi-year IEP is developed. Multi-year IEPs must include (a) measurable goals coinciding with natural transition points for the child, and (b) measurable annual goals for determining progress toward meeting the goals coinciding with natural transition points. measuring them to determine if a student is making meaningful progress in academic and functional areas. Finally, the law stresses the critical importance of grounding special education services in scientific, research-based procedures.

The IDEIA also includes changes to the transition requirements of the IEP. The requirement in the IDEA
Amendments of 1997 that IEP teams must consider transition activities when a child turns 14 years of age has been removed from the federal law. A student's IEP team now must address the transition needs and services for the student when he or she turns 16; however, states may choose to continue beginning the IEP transition requirement at age 
14. When IEP meetings regarding transition services are scheduled, the student must be invited to attend. If the student does not attend the IEP meeting, the IEP team must take other steps to ensure that the student's preferences and interests are considered when developing the transition IEP. Moreover, the transition IEPs now must also include appropriate measurable postsecondary goals based upon ageappropriate transition assessments related to training, education, employment, and, where appropriate, independent living skills.

This change seemed to counter the purpose of IDEA '97's age 14 requirement, which responded partially to research findings indicating that transition services should start early, before students are at an age where they can drop out of school. This change provokes at least three major concerns:

1. Because students with disabilities drop out of schools at alarming rates and most of them start to drop out at age 16 , those who really need transition services may have no chance to benefit from the services because they have already left school (Thurlow, Sinclair, \& Johnson, 2002; Christenson, Hurley, \& Evelo, 1998; Dunn, Chambers, \& Rabren, 2004; Kortering \& Braziel, 1998; Scanlon \& Mellard, 2002).

2. A great number of students who decide to stay in school will not be able to pursue postsecondary education in a meaningful and realistic way. They, therefore, need to take a different pathway and be prepared for life after school (Greene, 2003).

3. A different set of curriculum must be planned and implemented for these students early enough so they will have time to complete the courses of study. Starting at age 16 is simply too late for many students, especially those with cognitive limitations. Possibly in anticipation of this concern, Congress proactively included the wording "earlier, if appropriate" in the transition age mandate so LEAs can start planning transition services for certain students before age 16 , if needed.

Given these concerns and flexibility in the law, building administrators and secondary/transition personnel must make an effort to identify students who really need transition services. IEP teams should be encouraged to start planning these students' courses of study and transition services before they reach age 16. A number of proven practices can be useful in this process. One of these is the "transition pathways model" (Greene, 2003). In this model, four transition pathways are available for students with various ability/disability levels. Each of the pathways is designed to meet the needs of a group of students and contains recommendations regarding instruction, community experiences, employment and other postsecondary adult living objectives, and functional vocational evaluation and daily living skills. Another feature of this model is the matching of transition-planning activities with these areas of needs. Implementation of this or any other appropriate models will improve the transition outcomes of students with disabilities.

\section{Development of the IEP}

Five specific measures were included in IDEIA to alleviate what members of Congress perceived as the excessive paperwork requirement of the law:

1. IEP team members may be excused from all or parts of an IEP meeting if parents and the school agree in writing that the team member isn't needed because his or her services aren't being discussed or modified. In these situations, the team member must submit written input into the IEP's development before the meeting begins.

2. If an initial IEP meeting has been held and an IEP has been adopted, parents can agree with the IEP team members to modify the IEP in writing without holding a formal meeting. This agreement should be signed and attached to the IEP.

3. The IEP team may agree to conduct IEP meetings and other meetings by using alternate means (e.g., videoconferencing, conference calls), and districts are encouraged to consolidate meetings when possible (e.g., IEP team meetings and reevaluation meetings).

4. When an eligible child with an IEP transfers school districts within the same academic year within the same state, the receiving district must provide FAPE, including services comparable to those described in the previous IEP in consultation with the parents, until the district adopts the previous IEP or develops a new IEP. For out-of-state transfers, the district must provide the child with FAPE including services comparable to those described in the previous IEP, in consultation with the parents until the LEA conducts an evaluation, if the LEA determines to be necessary, and develops a new IEP, if appropriate.

5. IDEIA allows for a 15-state demonstration program, with written consent of the parent, to develop comprehensive multi-year IEPs (not to exceed 3 years). States desiring to participate in the program must submit proposals to request such an option. The proposal must include

a. assurances that the development of a multi-year IEP is optional for parents and their informed consent is required;

b. a list of required elements for each multi-year IEP, including measurable goals coinciding with natural transition points for the child; and 
c. a description of the process for the review and revision of each multi-year IEP.

\section{Simplifying the Discipline Process}

In IDEIA, Congress simplified the discipline process while continuing the emphasis on addressing discipline through the IEP process. We will briefly review the changes that Congress made to the disciplinary provisions of IDEA.
Table 4 depicts the changes to the IDEA's procedural safeguards, including the disciplinary changes.

\section{Short-Term Disciplinary Removals}

School personnel may remove a child with a disability who violates a code of student conduct from their current placement to an appropriate interim alternative educational setting, another setting, or may suspend the student for not

TABLE 4

IDEA 2004: Procedural Safeguards, Section 615

Key Points Explanation

Statute of limitations Hearings: LEAs or a parent shall request an impartial due process hearing within 2 years of the date of action in dispute or, if the state has an explicit time limitation for requesting such a hearing under this part, in such time as the state law allows.

Civil actions: LEAs or a parent shall request action within 90 days from the date of the decision of the hearing officer or, if the state has an explicit time limitation for bringing such action under this part, in such time as the state law allows.

Resolution session Prior to a hearing, the LEA shall convene a meeting, within 15 days, with the parents and the relevant member or members of the IEP team who have specific knowledge of the facts identified in the complaint.

The meeting shall include a representative of the agency who has decision-making authority and may not include an attorney of the local education agency unless the parent is accompanied by an attorney.

The parents of the child will discuss their complaint, and the facts that form the basis of the complaint, to allow the LEA the opportunity to resolve the complaint.

LEAs and parents may agree in writing to waive such meeting, or agree to use the mediation process.

Basis for decision Decisions shall be made on substantive grounds based on a determination of whether the child received a free appropriate public education. Procedural violations may constitute denial of FAPE, if they impeded the child's right to FAPE, significantly impeded the parents' opportunity to participate in the decision, or caused deprivation of educational benefits.

Discipline authority of school personnel

School personnel may consider any unique circumstances on a case-by-case basis when determining whether to order a change in placement for a child with a disability who violates a code of student conduct.

IAES

Placement for up to 45 school days without regard to whether the behavior is determined to be a manifestation of the child's disability in cases in which a child carries or possesses a weapon, knowingly possesses or uses illegal drugs, or sells or solicits the sale, or has inflicted serious bodily injury.

Manifestation determination
The team is to consider whether the conduct in question was caused by, or had a direct and substantial relationship to, the child's disability; or if the conduct in question was the direct result of the LEA's failure to implement the IEP. 
more than 10 consecutive school days (to the extent that such alternatives are applied to children without disabilities), and for additional removals of not more than 10 consecutive school days in the same school year for separate incidences of misconduct (as long as the removals do not constitute a change of placement). Furthermore, school personnel may consider any unique circumstances on a caseby-case basis when determining whether to order a change in placement for a child with a disability who violates a code of student conduct.

If school personnel seek to order a change in placement that would exceed 10 school days and the behavior that gave rise to the violation of the school code is determined not to be a manifestation of the child's disability, the relevant disciplinary procedures applicable to children without disabilities may be used. We discuss these procedures now.

\section{Long-Term Disciplinary Removals}

In IDEIA, Congress allowed school personnel to remove a student to an interim alternative educational setting (IAES) for no more than 45 school days without regard to whether the behavior is determined to be a manifestation of the child's disability in cases where a child

- carries or possesses a weapon;

- knowingly possesses or uses illegal drugs, or sells or solicits the sale of illegal drugs; and

- inflicts serious bodily injury upon another person while at school, on school premises, or at a school function.

The two significant changes are as follows:

1. The length of time that school personnel may remove a student unilaterally to an interim alternative setting has been changed from 45 calendar days to 45 school days.

2. In addition to removing students for weapon or drug offenses, school personnel may remove a student who has inflicted serious bodily injury upon another person while at school.

A child with a disability who is removed from his or her current placement because of weapons, drugs, or infliction of injury or because of violation of school code-irrespective of whether the behavior is determined to be a manifestation of the child's disability - must continue to receive educational services that enable the child to continue to participate in the general education curriculum and receive the services required in the IEP. The student also should receive a functional behavioral assessment, behavioral intervention services and modifications designed to address the behavior violation so it does not recur.

\section{Manifestation Determination}

The manifestation determination component also has been simplified. Schools must convene the IEP team within 10 school days of any decision to change the placement of a child because of a violation of a code of student conduct, or in connection with misconduct involving weapons or illegal drugs, or infliction of serious bodily injury. The IEP team must review relevant information in the student's file, including the child's IEP, any teacher observations, and any relevant information provided by the parents. Then the team must answer the following two questions:

1. Was the conduct in question caused by, or did it have, a direct and substantial relationship to, the child's disability?

2. Was the conduct in question the direct result of the local education agency's failure to implement the IEP?

If the conduct was a manifestation of the child's disability, the IEP team shall conduct a functional behavioral assessment and implement a behavioral intervention plan for the child. In the situation where a behavioral intervention plan has been developed, the team is expected to review the plan and modify it as needed to address the behavior. The major change in this section is to include the language requiring a direct relationship between the misbehavior and the disability or the misbehavior and the failure to implement the IEP.

\section{Educational Services}

The IDEIA also clearly requires that, after a student has been removed from his or her current placement for 10 school days in the same school year, if the student incurs any subsequent suspension or removal, the school must provide educational services to enable the student to continue to participate in the general education curriculum (although in another setting) and to progress toward the annual goals set forth in his or her IEP. These services must be determined by the IEP team and should include a functional behavioral assessment and behavioral interventions and services designed to address the problem behavior so it does not recur. Furthermore, the IEP team must determine the interim alternative educational setting in which the student will receive services.

\section{Altering the Dispute Resolution Process}

In IDEIA Congress also addressed the prevention of disputes and improvement of the dispute-resolution process. Whereas in IDEA 1997 Congress introduced mediation procedures to the special education dispute-resolution process, in IDEIA Congress introduced a resolution component into 
this process. The law now includes a requirement that a resolution session must take place between the parents and the local education agency, along with relevant members of the IEP team who are knowledgeable about the facts of the case, prior to a due process hearing. The conditions for conducting a resolution hearing are as follows:

1. The meeting must be held within 15 days of receiving the parental complaint.

2. The meeting must include a representative of the agency who has decision-making authority on behalf of the LEA.

3. An attorney may be present only if both parties have attorneys at the session.

4. The parents must discuss their complaint with the school district personnel, thereby allowing the school district the opportunity to resolve the complaint.

If the complaint is not resolved, a hearing will take place within 30 days of the parental complaint, and all current timelines for a due process hearing will be in effect.

\section{Flexibility in Funding}

School districts may use up to $15 \%$ of federal funds annually, combined with other funds, for coordinated early intervening services for students $\mathrm{K}-12$ (focusing on $\mathrm{K}-3$ ) not identified as needing special education and related services, but who need extra academic and behavioral support in general education. Funds may be used for providing (a) professional development for teachers and other school staff on scientifically based academic and behavioral interventions, including scientifically based literary instruction and, where appropriate, instruction on the use of adaptive and instructional software; and (b) educational and behavioral evaluations, services, and supports, including scientifically based literacy instruction (IDEA Regulations, 34 C.F.R. § $300.226(a-b))$.

For example, school districts may use IDEA funds to adopt schoolwide positive behavior support. Positive behavior support (PBS) is defined by the OSEP Technical Assistance Center on Positive Behavioral Interventions and Supports as a "broad range of systematic and individual strategies for achieving important social and learning outcomes while preventing problem behavior" (Sugai \& Horner, 2004, p. 29). Schoolwide PBS consists of research-based practices that create a continuum of behavior supports for all students in a school, as well as for students with challenging behavior.

\section{Additional Changes in IDEIA}

In this article we have explored some of the significant changes in IDEIA. We have not addressed additional changes that will affect special education. Some of these changes are included in Table 5.

\section{RECOMMENDATIONS FOR SPECIAL EDUCATORS, ADMINISTRATORS, AND TEACHER TRAINERS}

The overarching implication of IDEIA is that special educators must address more than procedural compliance. They now must develop meaningful educational programs, grounded in research-based practices, that produce results that improve the lives of students with disabilities. Indeed, to ensure that they are meeting the requirements of IDEIA, administrators should focus on improving educational results for students in special education programs. We offer the following suggestions to assist special educators, administrators, and teacher trainers to meet these challenges.

\section{Recommendation \#1: Ensure that teachers and administra- tors understand the essence of the IDEA.}

IDEA is a complex law, and special educators, administrators, and teacher trainers must understand the essence of the IDEA: Special education exists to provide educational services to children and youth with disabilities who (a) have a disability covered by the law and (b) need special education services to learn. Because general education has not met a student's unique educational needs, he or she requires a "special" education that is individualized and results in meaningful educational benefit. To ensure that public schools fulfill these obligations, special educators must

- conduct relevant assessments of students that provide information to teachers concerning a student's unique academic and functional needs and how best to address those needs;

- develop, based on the assessment, meaningful educational programs for students, consisting of special education and related services grounded in researchbased practices;

- generate measurable annual goals that will be used to monitor a student's academic and functional progress;

- monitor the student's progress by collecting data on his or her growth toward those goals, and make instructional changes when necessary.

IDEIA emphasizes the importance of meaningful programming by stressing the importance of the substantive requirements of the law.

Recommendation \#2: Ensure that special education teachers understand and use research-based procedures.

The importance of using research-based educational procedures is stressed in both NCLB and IDEIA. Too often, schools have used programs and practices based on fads, 


\section{TABLE 5 \\ Additional Issues}

\section{IDEIA}

\section{Key Points}

NCLB alignmenthighly qualified personnel

Adequate yearly progress (AYP)

Paperwork reduction

Prohibition of mandatory medication

\section{Schoolwide programs}

Early intervention services

\section{Overidentification and disproportionality}

Definition of parent

Surrogate parents

\section{Explanation}

Each person employed as a special education teacher in the state who teaches elementary school, middle school, or secondary school is highly qualified by the deadline established by NCLB (Section 612(a)(14)(C)); In addition to NCLB requirements, special education teachers must have full state special education certification (Section 602(10)(B)(i)). Teachers teaching multiple subjects must demonstrate competence in all the core academic subjects (Section 602(10)(D)(ii)).

A state's goals for the performance of children with disabilities are the same as the state's definition of adequate yearly progress, including the state's objectives for progress by children with disabilities, under NCLB (Section 612(a)(15)(A)).

Up to 15 states may apply for a waiver for 4 years. Waivers of statutory requirements may be granted to states to reduce paperwork burdens and other administrative duties necessary to increase the time and resources available for instruction and other activities related to improving outcomes (Section 609(a)).

State and LEA personnel are prohibited from requiring a child to obtain a prescription for a "controlled substance" as a condition of attending school (Section 612(a)(25)(A)).

LEAs may use funds received under IDEA to carry out a schoolwide program under NCLB (Title I) (Section 613(a)(D)).

LEAs may use up to $15 \%$ of IDEA funds to develop and implement coordinated, early intervening services, which may include interagency financing structures, for students in $\mathrm{K}-12$ (with an emphasis on $\mathrm{K}-3$ ) who need additional academic and behavioral support though not yet IDEA-verified (Section 613(f)(1)).

SEAs to adopt policies and procedures to prevent inappropriate identification or disproportionate representation by race and ethnicity (Section 612(a)(24)).

The definition is expanded to include "natural, adoptive, or foster parent"; guardian (but not the state if a ward); or person acting for natural or adoptive parent with whom the child lives or is legally responsible (Section 602(23)).

SEAs/LEAs must establish procedures to protect the rights of the child whenever the parents of the child are not known, the agency cannot, after reasonable efforts, locate the parents, or the child is a ward of the state, including the assignment of an individual to act as a surrogate for the parents (must be impartial) (Section 615(b)(2)(A)).

(continued) fancy, and personal bias, which have proven to be ineffective (Carnine, 2000). Unfortunately, this often is applicable to special education. Because of the IDEA's requirement that special education programs deliver meaningful benefit, when ineffective instructional strategies are used, this level of benefit likely will not be realized. Thus, when teachers rely on unproven programs and strategies, it is at the expense of students.

Therefore, administrators must engage in (a) hiring practices that emphasis the importance of their teachers' 
TABLE 5

(continued)

IDEA 2004

\section{Key Points}

Alternate assessments

Related services

Child Find

Children in private school

Legal fees

Monitoring, technical assistance, and enforcement

\section{Explanation}

Alternate assessments must be aligned with challenging academic content standards and challenging student academic achievement standards unless state has adopted alternate achievement standards, in which case students are measured against those standards (Section 612(a)(16)).

School nurse services were added to list of possible services (Section 602(26)).

Homeless children and wards of the state added to those placed in private schools who must be identified, located, and evaluated (Section 612(a)(3)).

State and local funds may supplement, but not supplant, proportionate amount of IDEA funds spend on services; LEA must report to state the number of children evaluated, determined eligible, and served (Section 612(a)(10)).

In addition to award of fees to parents, court may award fees to prevailing SEA/LEA against parents' attorney who (a) filed complaint or other cause of action that is frivolous, unreasonable, or without foundation, or (b) continued to litigate after action clearly became frivolous, unreasonable, or without foundation. Also, fees may be awarded for complaint or subsequent cause of action that was presented for any improper purpose, such as to harass, to cause unnecessary delay, or to needlessly increase the cost of litigation. (Section 615(i)).

Secretary shall monitor implementation of law through oversight of general supervisory responsibility and state performance plans (states required to monitor and enforce LEAs' implementation). Primary focus of monitoring is to improve educational results and functional outcomes for students with disabilities. Enforcement procedures are also articulated (Section 616(e)). knowing and using research-based practices, and (b) arranging professional development activities that ensure that their teachers understand and can properly implement educational practices that are based on the latest research. Quite simply, special education programming must produce meaningful educational benefit, and the way administrators can ensure that this happens is by requiring and assisting their teachers to use what works.

In addition to understanding and being able to implement research-based practices, special educators will require in-depth knowledge of available resources and be able to distinguish legitimate research from fads and slicksounding sales pitches. And special educators must develop collaborative relationships with individuals in local colleges and universities who train special education teachers.
The websites listed in Figure 3 offer useful sources of information on research-based practices.

Recommendation \#3: Ensure that special education teachers know how to collect and use formative data to monitor student progress.

IDEIA increases the federal mandate that requires teachers to monitor student progress. It accomplishes this in four major ways:

1. The law requires that IEP team members develop measurable annual goals in each student's IEP.

2. The IEP must delineate how these goals will be measured, through a progress-monitoring system. 
- Institute on Violence and Destructive Behavior: http://www.uoregon.edu/ ivdb/

- National Center on Educational Outcomes: http://education.umn.edu/nceo/

- National Center on Education, Disability, and Juvenile Justice: http://www.edjj.org/

- National Center on Secondary Education and Transition: http://www.ncset.org/

- National Center on Student Progress Monitoring: http://www.studentprogress.org/

- National Center to Improve the Tools of Educators: http://idea.uoregon.edu/ ncite/

- National Research Center on Learning Disabilities: http://www.nrcld.org/publications/index.shtml

- Office of Special Education Programs: http://www.ed.gov/offices/OSERS/OSEP/

- OSEP Publications and Products: http://www.ed.gov/offices/OSERS/OSEP/Products/

- Promising Practices Network: http://www.promisingpractices.net

- Technical Assistant Center on Positive Behavioral Interventions and Supports: http://www.PBIS.org

- What Works Clearinghouse: http://whatworks.com

\section{FIGURE 3 \\ Suggested Websites on Evidence-Based Practices}

3. Special education teachers must monitor a student's progress toward meeting these annual goals at least every 9 weeks and report the student's progress to his or her parents.

4. Teachers must make instructional changes when a student's progress is not sufficient to achieve his or her goals. The law requires that

(a) students have annual goals that can be measured,

(b) teachers actually measure progress toward these goals, and

(c) instructional changes be made when a student is not progressing.

As we have discussed in this article, the obligation of administrators and special educators is to develop and deliver individualized special education programs that confer meaningful education benefits to students served under IDEA. To ensure that special education teachers deliver a meaningful educational program and, thus, meet the requirements of IDEA, they must be able to collect data to determine if the programs are working and their students are making progress toward meeting their measurable annual goals.

Collecting summative data at the end of a program is not sufficient; rather, teachers should be collecting formative data during the course of instruction. In this way, teachers will have objective data to guide their instructional decisions. If the data show that a student is not learning, the teacher can make instructional changes and continue to collect data to determine if the instructional changes are working. Thus, teachers can adjust their instruction in response to student performance (Yell \& Stecker, 2003).
Although existing data-collection systems can result in improved instructional programs, special educators often do not use these systems (Deno, 1992). Administrators should insist that their special education teachers use a progress-monitoring system. In this way, they can help to ensure that special education programs provide meaningful educational benefit. The Office of Special Education Program in the U.S. Department of Education funds the National Center on Student Progress Monitoring. The center offers frequent training and assistance in adopting progress monitoring systems. The center's URL is http://www.student progress.org/.

Recommendation \#4: Ensure that special education teachers understand how to develop educationally meaningful and legally sound IEPS.

Administrators should ensure that programming focuses on meaningful programming and progress monitoring and move away from merely emphasizing procedural compliance. As Yell and Drasgow (2005) noted, teachers need to make sound decisions about the instructional programs and procedures they use and be able to revise the programs when needed, by understanding how to monitor a student's progress. Administrators, therefore, have to understand the IEP process and ensure that their special education teachers are developing educationally meaningful and legally correct IEPs.

To ensure that IEPs are educationally meaningful and legally correct, special educations must

- conduct assessments that address a student's instructional needs, 
- develop meaningful special education that uses research-based strategies and procedures,

- collect data to monitor student progress and plan and adjust instruction based on the data, and

- report a student's progress to his or her parents.

Individualized education programs that are based on inadequate assessments, contain goals that are not individualized or appropriate (e.g., goals from a computer goal bank that are the same for all students and that are not measurable), and have no progress-monitoring component most likely will not provide educational benefit and probably will not pass legal muster.

Recommendation \#5: Ensure that special education teachers receive meaningful and sustained inservice training programs in new research-based practices and other developments in special education.

Of paramount importance, administrators must ensure that all teachers, including teachers in special education, have the necessary skills and tools to implement evidencebased practices. There is a huge gap between (a) what we know works from scientifically based research, and (b) what actually is taught in many classrooms (Yell \& Drasgow, 2005). Maag and Katsiyannis (2003) suggested that educators should base their intervention decisions on the extant data and ignore anecdotal and testimonial reports. Indeed, educators should avoid jumping on the latest fad and, instead, implement interventions that have a proven track record and wait until a body of research has been established.

Teacher trainers must prepare teachers to be fluent in research-based practices and also know how to access research through peer-reviewed literature. Administrators must develop mechanisms to ensure that teachers receive regular and frequent inservice training experiences in the latest peer-reviewed research. Moreover, when an administrator evaluates a teacher, he or she should assess the extent to which the teacher uses research-based practices.

\section{CONCLUSIONS}

The IDEIA and the implementing Regulations provide many opportunities for educators to ensure that their special education programs provide meaningful educational opportunities for the students with disabilities they serve. The law streamlines the IEP and discipline process and emphasizes results over process. Perhaps two of the most significant changes in the IDEIA are

1. the requirement that states can no longer require school districts to use discrepancy formulas to determine eligibility for special education services in the category of learning disabilities and may prohibit the practice (depending on the language on the final Regulations), and

2. the requirement that special education services should be based on peer-reviewed research.

Certainly, as a result of IDEIA, special educations and administrators may spend more of their time attending to the quality of their special education programs and the results attained by their students with disabilities rather than worrying exclusively about the procedural requirements of the law.

\section{REFERENCES}

Browder, D., Karvonen, M., Davis, S., \& Fallin, K. (2005). The impact of teacher training on state alternate assessment scores. Exceptional Children, 71(3), 267-282.

Carnine, D. (2000). Why education experts resist effective practices and what it would take to make education more like medicine. Retrieved March 11, 2006, from http://www.edexcellence.net/foun dation/global/found.cfm?author=72\&keyword=\&submit=search

Christenson, S. L., Hurley, C., \& Evelo, D. (1998). Dropout prevention for high-risk youth with disabilities: Efficacy of a sustained school engagement procedure. Exceptional Children, 65, 7-21.

Deno, S. L. (1992). The nature and development of curriculum-based measurement. Preventing School Failure, 36(2), 5-10.

Dunn, C., Chambers, D., \& Rabren, K. (2004). Variables affecting students' decisions to drop out of school. Remedial and Special Education 25(5), 314-324.

Finn, C. E., Rotherham, A. J., \& Hokanson, C. R. (Eds.) (2001). Conclusions and principles of reform. In C. E. Finn, A. J. Rotherham, \& C. R. Hokanson (Eds.), Rethinking special education for a new century (335-347). Washington, DC: Thomas B. Fordham Institute. Retrieved March 7, 2005, from http://www.ppionline.org/ ppi_ci.cfm?knlgAreaID=110\&subsecID=181\&ontented $=3344$

Gong, B., \& Marion, S. (2006). Dealing with flexibility in assessments for students with significant cognitive disabilities. National Center for the Improvement of Educational Assessment, Inc. Retrieved April 25, 2006, from www.naacpartners.org/Products/Files/Gong \%20\&\%20Marion\%20assessment\%20flexibility_041306.pdf

Greene, G. (2003). Transition pathways. In G. Greene \& C. A. Kochhar-Bryant, Pathways to successful transition for youth with disabilities (pp. 198-229). Upper Saddle River, NJ: Merrill.

Hassel, B. C., \& Wolf, P. J. (2001). Effectiveness and accountability (Part 2): Alternatives to the compliance model. In C. E. Finn, A. J. Rotherham, \& C. R. Hokanson (Eds.), Rethinking Special Education for a New Century (309-333). Washington, DC: Thomas Fordham Foundation. Retrieved March 7, 2005, from http://www. ppionline.org/ppi_ci.cfm?knlgAreaID $=110 \&$ subsecID $=181 \&$ ontented $=3344$

H.R. Rep. No. 77 108th Cong., 1st Sess. (2003). Improving Educational Results for Children with Disabilities Act of 2003.

Individuals with Disabilities Education Improvement Act, H.R. 1350, 108th Congress (2004).

Individuals with Disabilities Education Improvement Act Regulations (August 3, 2006). Downloaded on August 3, 2006, from http://www.ed.gov/policy/speced/guid/idea/idea2004.html 
Kleinert, H., \& Kearns, J. (2004). Alternate assessments. In F. Orelove, D. Sobsey, \& R. Silberman (Eds.), Educating children with multiple disabilities: A collaborative approach (4th ed.) (pp. 115-149). Baltimore: Paul Brookes.

Kortering, L. J., \& Braziel, P. M. (1998). School dropout among youth with and without learning disabilities. Career Development for Exceptional Individuals, 34, 61-72.

Maag, J. W., \& Katsiyannis, A. (2003). Practical considerations for selecting educational methodologies. Principal Leadership, 4(2), 35-38.

No Child Left Behind Act of 2001, 20 U.S.C. 70 Section 6301 et seq.

No Child Left Behind Act of 2001 Regulations, 34 CFR Part 200. Retrieved March 21, 2005, from http://www.ed.gov/legislation/ FedRegister/finrule/2003-4/120903a.html

Pullin, D. (2005). When one size does not fit all: The special challenges of accountability testing for students with disabilities. In E. Haertel \& J. Herman (Eds.), Annual Yearbook of the National Society for the Study of Education. 104(2), pp. 199-222.

Rouse, M., Shriner, J., \& Danielson, L. (2000). National assessment and special education in the United States and England and Wales. In M. McLaughlin \& M. Rouse (Eds.), Special education and school reform in the United States \& Britain (pp. 66-97). London: Routledge.

Scanlon, D., \& Mellard, D. F. (2002). Academic and participation profiles of school-age dropouts with and without disabilities. Exceptional Children, 68(2), 239-258.

Sireci, S. G., Scarpati, S. E., \& Li, S. (2005). Test accommodations for students with disabilities: An analysis of the interaction hypothesis. Review of Educational Research, 75, 457-490.

Sugai, G., \& Horner, R. H. (2004). The evolution of discipline practices: School-wide behavior supports. Child and Family Behavior Therapy, 24, 23-50.

Thurlow, M. L. (2006, March). Accommodations in state policies: What a wonderful world of diversity. Presentation at Educational Testing Service Conference on Accommodation of Students with Disabilities on State Assessments, Savannah, GA.

Thurlow, M. L., Sinclair, M. F., \& Johnson, D. R. (2002). Students with disabilities who drop out of school-Implications for policy and practice. Issue Brief, 1(2), 1-7.
Tindal, G. (2006, March). Accommodations research: Reconsidering the test accommodation validation process. Presentation at Educational Testing Service Conference on Accommodation of Students with Disabilities on State Assessments, Savannah, GA.

Title I-Improving the Academic Achievement of the Disadvantaged; Individuals with Disabilities Education Act (IDEA)-Assistance to States for the Education of Children with Disabilities; Proposed Rule, 70 Fed Reg. 74624 (2005) (34 C.F.R. § 200 and 300).

U.S. Department of Education. (2002). A new era: Revitalizing special education for children and their families. Washington, DC: President's Commission on Excellence in Special Education. Retrieved March 21, 2005, from http://www.ed.gov/inits/commissions boards/whspecialeducation/reports/index.html

U.S. Department of Education. (2005a, August 9). Alternate achievement standards for students with the most significant cognitive disabilities: Non-regulatory guidance. Retrieved on August 22, 2006, from http://www.ed.gov/admins/lead/account/saa.html\#guidance

U.S. Department of Education. (2005b). Individuals with Disabilities Education Act (IDEA) data. Retrieved March 21, 2005, from http://www.ideadata.org/PartBReport.asp

Whitehurst, G. J. (2002). Evidence-based education. Retrieved September 10, 2001, from http://www.ed.gov/nclb/methods/what works/eb/evidencebased.pdf

Yell, M. L., \& Drasgow, E. (2005). No Child Left Behind: A guide for professionals. Upper Saddle River, NJ: Pearson/Merrill/Prentice Hall.

Yell, M. L., Drasgow, E., \& Lowrey, K. A. (2005). No Child Left Behind and students with autism spectrum disorders. Focus on Autism and Other Developmental Disorders, 20, 130-139.

Yell, M. L., \& Shriner, J. G. (1997). The IDEA Amendments of 1997: Implications for special and general education teachers, administrators, and teacher trainers. Focus on Exceptional Children, 30(1), $1-20$.

Yell, M. L., \& Stecker, P. M. (2003). Developing legally correct and educationally meaningful IEPs using curriculum-based measurement. Assessment for Effective Intervention, 28, 73-88. 